\title{
Article \\ Effect of Deep Cryogenic Treatment on Corrosion Properties of Various High-Speed Steels
}

\author{
Jure Voglar ${ }^{1}$, Živa Novak ${ }^{1}$, Patricia Jovičević-Klug ${ }^{2,3}{ }^{(D}$, Bojan Podgornik ${ }^{2}$ and Tadeja Kosec ${ }^{1, *(D)}$ \\ 1 Slovenian National Building and Civil Engineering Institute, Dimičeva ulica 12, 1000 Ljubljana, Slovenia; \\ jure.voglar@zag.si (J.V.); ziva.novak@zag.si (Ž.N.) \\ 2 Institute of Metals and Technology, Lepi pot 11, 1000 Ljubljana, Slovenia; \\ patricia.jovicevicklug@imt.si (P.J.-K.); bojan.podgornik@imt.si (B.P.) \\ 3 Jožef Stefan International Postgraduate School, Jamova cesta 39, 1000 Ljubljana, Slovenia \\ * Correspondence: tadeja.kosec@zag.si
}

Citation: Voglar, J.; Novak, Ž.; Jovičević-Klug, P.; Podgornik, B.; Kosec, T. Effect of Deep Cryogenic Treatment on Corrosion Properties of Various High-Speed Steels. Metals 2021, 11, 14. https://dx.doi.org/10.3390/ met11010014

Received: 10 December 2020 Accepted: 22 December 2020 Published: 24 December 2020

Publisher's Note: MDPI stays neutral with regard to jurisdictional claims in published maps and institutional affiliations.

Copyright: () 2020 by the authors. Licensee MDPI, Basel, Switzerland. This article is an open access article distributed under the terms and conditions of the Creative Commons Attribution (CC BY) license (https: / / creativecommons.org/ licenses/by/4.0/).

\begin{abstract}
The aim of the study was to evaluate the corrosion properties of three different grades of high-speed steel following a heat treatment procedure involving deep cryogenic treatment after quenching and to investigate how these properties are connected to the microstructure and hardness of the material. The hardness of steels was measured, and microstructural properties were determined through observation of the metallographically prepared steels using scanning electron microscopy. These studies were complemented corrosion evaluation by the use of corrosion potential measurement and linear polarization measurement of steels in a sodium tetraborate buffer at $\mathrm{pH} 10$. The results showed that the deep cryogenic procedure of high-speed steel changed the microstructure and consequently affected the hardness of the investigated steels to different extents, depending on their chemical composition. Corrosion studies have confirmed that some high-speed steels have improved corrosion properties after deep cryogenic treatment. The most important improvement in corrosion resistance was observed for deep cryogenically treated high-speed steel EN 1.3395 (M3:2) by $31 \%$ when hardened to high hardness values and by $116 \%$ under lower hardness conditions. The test procedure for differentiating corrosion properties of differently heat-treated tool steels was established alongside the investigation.
\end{abstract}

Keywords: deep cryogenic treatment; high-speed steels; microstructure; hardness; corrosion properties

\section{Introduction}

Tool steels are used in many industrial manufacturing processes, including machining, cutting, stamping, pressing, forging, and others [1]. During their lifetime, the tools (e.g., drills) are subject to demanding operating conditions such as high stresses, high temperatures, and their fluctuations. The harsh conditions wear tools such that they must eventually be replaced. The wear behavior and lifetime of the tools are affected by the properties of the tool steels [1]. The desired properties of tool steels are high hardness at both low and high temperatures, high compressive strength, fatigue strength, toughness at operational temperatures, wear resistance, thermal fatigue resistance, and corrosion resistance [1]. Tool steel properties depend on their chemical composition and heat treatment procedure, both of which affect their microstructure.

The conventional heat treatment of tool steels, normally done in a vacuum, consists of three stages: (i) Austenitization, (ii) quenching, and (iii) multi-stage tempering. Austenitization and quenching partially transform the austenite to martensite. Some fraction of austenite remains in the microstructure after quenching, which is called retained austenite. Tempering reduces the fraction of retained austenite and transforms it to martensite, and causes the secondary carbides to precipitate within the microstructure [1].

Cryogenic treatment refers to the treatment of materials below room temperature, which roughly can be separated into shallow cryogenic treatment (from 113-193 K) and 
deep cryogenic treatment (below $113 \mathrm{~K}$ ). The process of cryogenic treatment consists of three main phases: Cooling, soaking, and warming [2]. The cryogenic treatment of tool steels has been shown to improve hardness, wear resistance, and dimensional stability [3]. The main effects of deep cryogenic treatment on the microstructure of steel are (i) transformation of retained austenite into martensite, (ii) precipitation of finely dispersed carbides, and (iii) relaxation of residual stresses [4].

The effect of cryogenic treatment on the mechanical properties of tool steels has been extensively investigated and can be summarized as follows. Amini et al. [5] managed to improve hardness by $5 \%$ and observed an increase in wear resistance from $60 \%$ to $66 \%$ following deep cryogenic treatment on D2 tool steel. Das et al. [6] also observed an increase in hardness (approximately 5\% higher), as well as a significant increase in wear resistance (i.e., 8 times higher), during sliding wear tests on deep cryogenically treated D2 tool steel. Through deep cryogenic treatment, Firouzdor et al. [7] managed to improve the wear resistance of an M2 high-speed steel (HSS) drill in a high-speed carbon steel drilling configuration by up to $126 \%$, whereas the increase in hardness was less than $4 \%$. Kurik et al. [8], on the other hand, observed a slightly decreased hardness (up to 1 HRC) following both shallow and deep cryogenic treatment of AISI D2 cold work tool steel and powder metallurgy (PM) high-speed steel Vanadis 23. Oppenkowski et al. [9] investigated the effects of deep cryogenic treatment on the mechanical properties of PM cold-work tool steel AISI D2. They concluded that the deep cryogenic treatment shifts the secondary hardness peak towards a lower temperature. It has been established that the hardiness of the deep cryogenic treated AISI D2 steel is lower than in conventional heat treatment when the tempering temperature is above $500{ }^{\circ} \mathrm{C}$. Rhyim et al. [10] stated that the hardness would decrease as the tempering temperature increases, while the wear resistance and impact energy will simultaneously increase.

Amini et al. [5] studied the effect of cryogenic treatment on the microstructure of tool steels and observed a decrease in the volume fraction of retained austenite from $8 \%$ to less than $1 \%$, while the carbide content increased from $18 \%$ to $26 \%$. The distribution of carbides was more uniform as a consequence of the formation of micro-sized and nano-sized carbides during the cryogenic treatment of the D2 tool steel. After cryogenic treatment of AISI M2 HSS, Gill et al. [11] reported that the retained austenite (10.4 vol. \% after conventional treatment) completely transformed to martensite and that the precipitation of small secondary carbides was accelerated, thus increasing their volume fraction and promoting the uniform distribution of the carbides in the entire bulk of the material. In contrast to previous studies, Gavriljuk et al. [12] detected no fine carbide precipitation after holding AISI D2 tool steel at cryogenic temperatures for a long time. Very recent literature data reports on different aspects for improving mechanical properties [13-17]. The effect of deep cryogenic treatment (DCT) of metallic materials was thoroughly reviewed in [14]. Another research proves that DCT has an impact on the precipitation of carbides by increasing their volumetric fraction in high-speed steels (M2, M3:2, and M35) and density while reducing their mean size and inducing a more homogeneous distribution [15]. Further, the comparison of conventional and cryogenic treatment of AISI M3:2 high-speed steel was elaborated [16].

The vast majority of experimental work and research focused on the effects of cryogenic treatment on the mechanical properties, such as hardness, impact and fracture toughness, erosion wear resistance $[17,18]$, wear resistance $[7,18,19]$, microstructure $[20,21]$, and tribological properties $[6,18,22,23]$ of tool steels. Study of the corrosive behavior of cryogenically treated steels has, however, been very scarce and limited and focused primarily only on stainless steels [24]. Corrosion resistance and the capability to reform oxide protective layer after deep cryogenic treatment was studied and no changes were reported. Corrosion resistance was studied by standardized methods such as salt spray tests [24].

The aim of the present study is to evaluate the effect of deep cryogenic treatment on the microstructural properties in high-speed steels and subsequently on corrosion resistance. Deep cryogenic treatment was used in combination with conventional vacuum 
heat treatment protocols, carried out at different austenitizing and tempering temperatures and resulting in different hardness levels. By the use of different electrochemical methods, the effect of heat treatment on the corrosion resistance of high-speed steels was evaluated and related to microstructural properties and steel composition.

\section{Materials and Methods}

Three different commonly used grades of high-speed tool steel were selected for the current study, which was vacuum heat-treated according to the steel producers' recommended protocols with classical steps, as well as with the inclusion of deep cryogenic treatment between the stages of quenching and tempering. The heat-treated samples were then evaluated using the classical metallurgical method (microscopy), measured for hardness, and assessed with electrochemical methods to determine corrosion properties.

\subsection{Selection of Materials, Preparation of Samples, and Heat Treatment Procedures}

Three different high-speed tool steel grades (M2, M3:2, M35) were selected to study the influence of the chemical composition (i.e., carbon, vanadium, and cobalt content) on their corrosion properties after deep cryogenic treatment. High-speed steel A (M2) was the most common high-speed steel produced by the SIJ group with a conventional electro-slag remelting (ESR) metallurgical process. Steel B (M3:2) was a powder metallurgy high-speed steel produced by Zapp Materials, and steel C (M35) was an ESR produced high-speed steel from Dörrenberg Edelstahl. Table 1 details the chemical compositions of the selected steels. Chemical composition was determined by inductively coupled plasma optical emission spectrometry (ICP-OES) using an ICP-OES Agilent 720.

Table 1. Chemical compositions of selected tool steels with different designations * in weight percent.

\begin{tabular}{cccc}
\hline $\begin{array}{c}\text { Element } \backslash \text { Steel } \\
\text { Grade }\end{array}$ & $\begin{array}{c}\text { M2 */1.3343 } \\
* \text { /HS6-5-2 *** A }\end{array}$ & M3:2/1.3395/HS6-5-3 & \multicolumn{2}{c}{ M35/1.3243/HS6-5-2-5 } \\
C & 0.9 & 1.29 & 0.9 \\
Mn & 0.28 & 0.31 & 0.34 \\
S & 0.002 & 0.006 & 0.004 \\
Cr & 4 & 3.9 & 4.1 \\
Mo & 4.7 & 4.8 & 5.2 \\
W & 6.0 & 5.9 & 6.2 \\
V & 1.7 & 3.00 & 2.0 \\
Co & - & 0.69 & 4.5 \\
\hline
\end{tabular}

* ASTM A600-1999 designation, ** designation according to DIN 17350-1980, ${ }^{* * *}$ Designation according to DIN EN ISO 4957:2018.

All 3 steels were delivered in the form of peeled bars in soft annealed condition, from which disc-shaped specimens $(\Phi 15 \mathrm{~mm} \times 2 \mathrm{~mm})$ were machined, surface roughness $\left(R_{\mathrm{a}}=0.4 \mu \mathrm{m}\right)$, and heat-treated in a horizontal vacuum furnace Ipsen VTTC324-R with uniform high-pressure gas quenching. The tested samples were denoted with two-character abbreviations, the first character a letter to denote the steel grade (Table 1), and the second character a number associated with the specific heat treatment protocol. The odd numbers (1 and 3 ) indicated the conventional vacuum heat treatment procedure recommended by the steel producer, while the even numbers ( 2 and 4 ) represented the heat treatment procedures with deep cryogenic treatment. Treatments 1 and 2 were performed at high austenitizing temperatures and low tempering temperatures in order to obtain maximum values of hardness, while treatments 3 and 4 utilized lower austenitizing and higher tempering temperatures in order to facilitate lower hardness values within the working hardness range for each specific steel. Two sets of austenitizing/tempering conditions were used for steel grades A and B, while only high austenitizing/low tempering conditions were used for steel grade $C$ due to a lack of material and similarities with steel grade A.

The classical heat treatment of the investigated steels (Figure 1a) was conducted in 2 steps: Austenitization and quenching (A\&Q) and 3-stage tempering $(T)$. The first 
step of the classical heat treatment started by heating the samples in a vacuum up to the austenitization temperature $T_{\mathrm{A}}$ at a rate of $25 \mathrm{~K} / \mathrm{min}$. The samples were then kept at $T_{\mathrm{A}}$ for several minutes to homogenize the austenitic microstructure. At the end of the austenitization period, $t_{\mathrm{A}}$, the samples were quenched $(7.5 \mathrm{~K} / \mathrm{min})$ in nitrogen gas at a pressure of 5 bar to $80{ }^{\circ} \mathrm{C}$. Quenching was immediately followed by 3-stage tempering in a vacuum (step 2), performed in the same furnace, with the samples being heated to the desired tempering temperature, $T_{\mathrm{T}}$, kept there for the tempering period, $t_{\mathrm{T}}$, and then cooled back to room temperature at a cooling rate of $3.5 \mathrm{~K} / \mathrm{min}$.

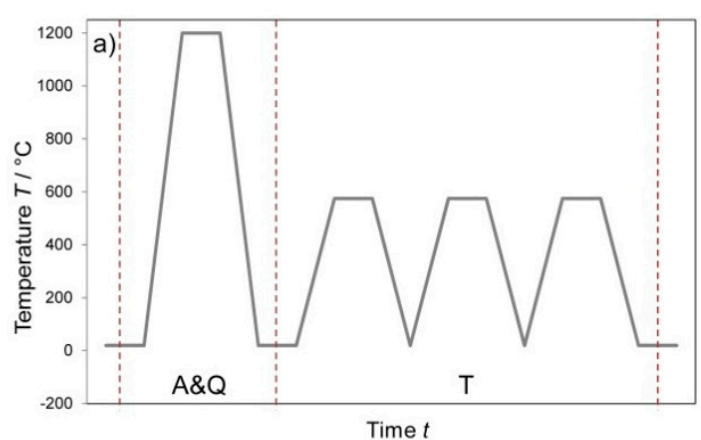

$\mathrm{A} 1$ and $\mathrm{C} 1: T_{\mathrm{A}}=1230^{\circ} \mathrm{C}, t_{\mathrm{A}}=2 \mathrm{~min}$

$\mathrm{A} 3$ and $\mathrm{B} 1: T_{\mathrm{A}}=1180^{\circ} \mathrm{C}, t_{\mathrm{A}}=2 \mathrm{~min}$

B3: $T_{\mathrm{A}}=1050^{\circ} \mathrm{C}, t_{\mathrm{A}}=6 \mathrm{~min}$
A1: $T_{\mathrm{T}}=550{ }^{\circ} \mathrm{C}, t_{\mathrm{T}}=3 \times 1 \mathrm{~h}$
A3: $T_{\mathrm{T}}=620^{\circ} \mathrm{C}, t_{\mathrm{T}}=3 \times 1 \mathrm{~h}$
B1: $T_{\mathrm{T}}=540{ }^{\circ} \mathrm{C}, t_{\mathrm{T}}=3 \times 2 \mathrm{~h}$
B3: $T_{\mathrm{T}}=600{ }^{\circ} \mathrm{C}, t_{\mathrm{T}}=3 \times 2 \mathrm{~h}$
C1: $T_{\mathrm{T}}=550^{\circ} \mathrm{C}, t_{\mathrm{T}}=3 \times 2 \mathrm{~h}$

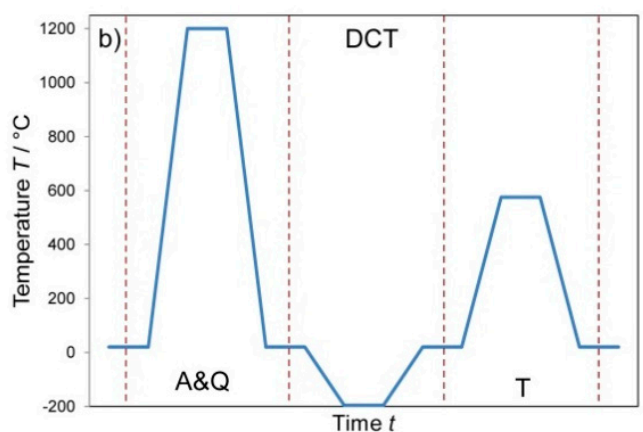

A2 and C2: $T_{\mathrm{A}}=1230^{\circ} \mathrm{C}, t_{\mathrm{A}}=2 \min \quad \mathrm{A} 2: T_{\mathrm{T}}=550^{\circ} \mathrm{C}, t_{\mathrm{T}}=1 \mathrm{~h}$ A4 and B2: $T_{\mathrm{A}}=1180^{\circ} \mathrm{C}, t_{\mathrm{A}}=2 \mathrm{~min} \quad \mathrm{~A} 4: T_{\mathrm{T}}=620^{\circ} \mathrm{C}, t_{\mathrm{T}}=1 \mathrm{~h}$ B4: $T_{\mathrm{A}}=1050^{\circ} \mathrm{C}, t_{\mathrm{A}}=6 \mathrm{~min} \quad \mathrm{~B} 2: T_{\mathrm{T}}=540^{\circ} \mathrm{C}, t_{\mathrm{T}}=2 \mathrm{~h}$ B4: $T_{\mathrm{T}}=600^{\circ} \mathrm{C}, t_{\mathrm{T}}=2 \mathrm{~h}$ C2: $T_{\mathrm{T}}=550^{\circ} \mathrm{C}, t_{\mathrm{T}}=2 \mathrm{~h}$

Figure 1. Parameters and schematic presentation of the conventional heat treatment procedure (a) and of the conventional heat treatment procedures with deep cryogenic treatment $(\mathbf{b})$.

Where the heat treatment procedure involved deep cryogenic treatment (DCT-treatments 2 and 4; Figure 1b), step 1 (A\&Q) was followed by the removal of specimens from the vacuum furnace and the samples were then subjected to deep cryogenic treatment. Deep cryogenic treatment was performed through controlled submersions of specimens into liquid nitrogen, followed by cooling from room temperature to $-196{ }^{\circ} \mathrm{C}(77 \mathrm{~K})$ at a cooling rate of $5 \mathrm{~K} / \mathrm{min}$. Once the samples reached the DCT temperature, they were soaked in liquid nitrogen for $24 \mathrm{~h}$, as reported to be the most effective in the case of tool steels [14], and then removed and left to warm back up to room temperature.

In addition, in the case of deep cryogenic treatment, the 3rd step of the heat treatment procedure was tempering. In this case, however, only single-stage tempering was performed, using the same parameters as in the conventional heat treatment.

After the heat treatment, the samples were prepared for microscopy and hardness measurements using classical metallographic methods. First, the disc samples were cast in the metallographic acrylic Buehler VariDur 200. The metallographic specimens were then prepared by consecutive grinding using $\mathrm{SiC}$ abrasive grinding papers with particle grit size ranging from $\mathrm{P} 600$ to $\mathrm{P} 4000$ and finally polished with alumina $\left(\mathrm{Al}_{2} \mathrm{O}_{3}\right)$ based polishing slurry with a grain size of $0.05 \mu \mathrm{m}$. The polished piece was then heated to $60{ }^{\circ} \mathrm{C}$ and etched with a $3 \%$ nital solution for an etching time ranging from 20 to $80 \mathrm{~s}$. Following polishing and etching, the specimen was cleaned with non-denatured $96 \%$ ethanol.

The samples for electrochemical measurements were prepared by grinding the heattreated steel discs with P320 and P1200 SiC abrasive grinding papers. Samples were then cleaned in an ethanol ultrasonic bath for $2 \mathrm{~min}$.

\subsection{Microscopy and Hardness Measurements}

The microstructure of the heat-treated samples was observed using scanning electron microscopy (SEM). The metallographically prepared samples were observed using SEM 
microscopes Jeol JSM 5500 LV and Jeol JSM IT500 LV. SEM observations took place in a high vacuum at an accelerating voltage of $20 \mathrm{kV}$.

The hardness of the heat-treated metallographically prepared samples was measured on 3 parallel specimens in 3 different locations, and the average values were calculated. Hardness was measured using the Frank Finotest 38542 in compliance with standard SIST EN ISO 6507-1:2018.

\subsection{Electrochemical Methods}

2.3.1. Testing of Aqueous Solutions for the Electrochemical Evaluation of High-Speed Steels

Different test solutions were 1st evaluated in order to obtain electrochemical parameters that could enable differentiating between different corrosion properties of high-speed steels. The electrochemical parameters measured in the optimal aqueous solution should enable sensible and relevant differentiation between the different heat-treated HSS samples with altered microstructures. Four different test solutions were evaluated: $0.1 \mathrm{M} \mathrm{NaCl}$, a Na-tetraborate buffer at $\mathrm{pH} 10$ with $0.1 \mathrm{M} \mathrm{NaCl}$, a Na-tetraborate buffer at $\mathrm{pH} 10$ with $1 \mathrm{mM} \mathrm{NaCl}$, and a Na-tetraborate buffer at $\mathrm{pH} 10$. The tests were made on grade $\mathrm{B}$ steel, namely B3 and B4 samples. Results are presented in Figure 2.
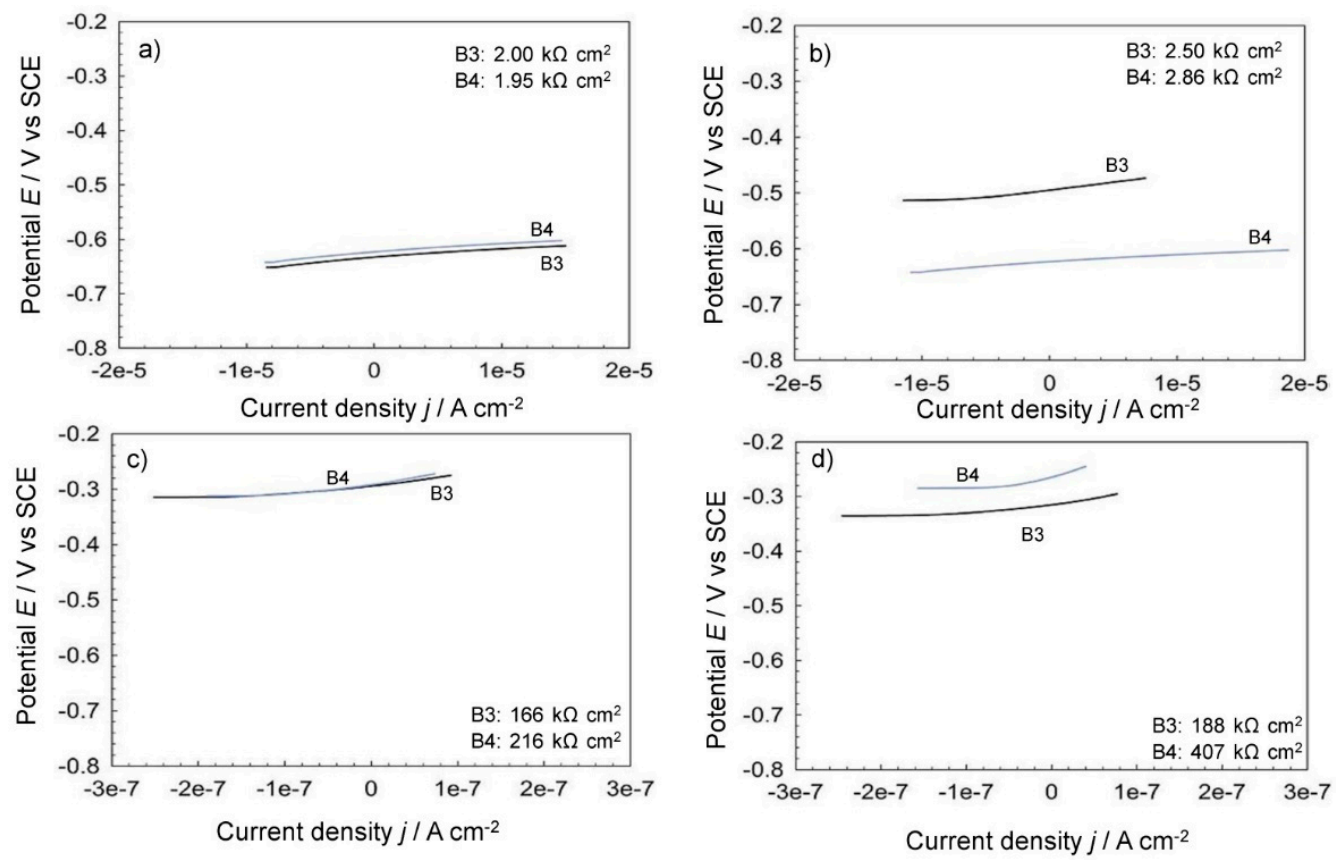

Figure 2. Linear polarization measurements of steel samples B3 (conventional heat treatment) and B4 (deep cryogenic treatment) conducted in four different test solutions: (a) $0.1 \mathrm{M} \mathrm{NaCl}$; (b) Na-tetraborate buffer pH 10 and $0.1 \mathrm{M} \mathrm{NaCl}$; (c) Na-tetraborate buffer $\mathrm{pH}$ 10, and $1 \mathrm{mM} \mathrm{NaCl}$; (d) Na-tetraborate buffer $\mathrm{pH} 10$ without chlorides.

The largest difference between polarization resistance values was observed in the Na- tetraborate buffer at $\mathrm{pH} 10$, where the $R_{\mathrm{p}}$ value (obtained by fitting a tangent to the $E / j$ curve at $j=0$ ) for deep cryogenically treated steel B4 was $116 \%$ higher than for the conventionally treated B3 steel sample. The results were obtained by repeating 6 individual measurements on each sample in each of the 4 test solutions. The selected $R_{\mathrm{p}}$ values were the ones closest to the average value of the 6 measurements in each case (results shown in Appendix A Figure A1). Further electrochemical measurements were conducted in a Na-tetraborate solution at $\mathrm{pH} 10$, where the passive film on high-speed steels was least soluble [25]. 


\subsubsection{Electrochemical Evaluation of High-Speed Steels}

A 3-electrode corrosion cell was used, with a saturated calomel reference electrode (SCE) serving as the reference electrode and graphite as the counter electrode. The exposed area of the working electrode measured $0.785 \mathrm{~cm}^{2}$. Tests were performed in a Na-tetraborate buffer at $\mathrm{pH}$ 10. Electrochemical tests were conducted using the Gamry Reference 600+ potentiostat and Gamry Frameworks software. All potentials in the text were in SCE scale. Firstly, open circuit potential (OCP) was measured for $1 \mathrm{~h}$. Secondly, a linear polarization scan was executed at a scan rate $0.1 \mathrm{mV} / \mathrm{s} \pm 20 \mathrm{mV}$ vs. $E_{\text {corr }}-$ corrosion potential. Each sample was measured at least three times in order to ensure reliable corrosion data, according to [26]. Linear polarization values were extracted by fitting a tangent to the $E / j$ curve at $j=0$. The linear polarization resistance value closest to the average value of $R_{\mathrm{p}}$ measurements of the sample, excluding the outliers, was selected.

\section{Results}

\subsection{Microstructure and Hardness of Samples}

The specimens of grade A steel (Figure 3) have a needle-like structure of martensite, and primary austenite grain boundaries can also be identified. The crystal boundaries of the primary austenite grains were more noticeable on the samples, which received deep cryogenical treatment (A2 and A4). All of the grade A steel samples contained carbides in the form of globules. Larger carbides are primarily located at the primary grain boundaries. The samples heat-treated conventionally had larger clusters of merged carbides than those deep cryogenically treated. The deep cryogenically treated samples (A2 and A4) showed some finer individual carbides. As a consequence of the different austenitization temperature, the crystal grains of the samples quenched from the upper austenitization temperature $\left(1230^{\circ} \mathrm{C}\right.$; A1 and A2) were slightly larger (from $15 \mu \mathrm{m}$ to $25 \mu \mathrm{m})$ than the crystal grains of the samples austenitized at a lower temperature $\left(1180^{\circ} \mathrm{C}\right.$; A3 and A4), which were between $10 \mu \mathrm{m}$ and $25 \mu \mathrm{m}$.

In accordance with the applied austenitization and tempering temperatures, the hardness of samples A3 and A4 was approximately $20 \%$ lower compared to samples A1 and A2 (674-744 HV vs. 864-896 HV; Figure 6). The deep cryogenic treatment procedure of the grade A steel caused a small increase in hardness (3.7\%) under high austenitization and low tempering temperature conditions (samples A1 and A2). There was, however, a considerable improvement in hardness, from 674 to $744 \mathrm{HV}(10.4 \%$ increase) when deep cryogenic treatment was implemented under low austenitization and high tempering temperature conditions (from A3 to A4). These results are shown in Figure 6.

The microstructure of the samples of grade B steel primarily consisted of tempered martensite with a needle-like structure. There were no visible grain boundaries (Figure 4). Black spots appeared in the microstructure of grade B samples, which were most likely non-metallic inclusions or voids formed during the preparation of the metallographic specimens. The volume fraction of the carbides was the highest amongst all of the tested steel grades due to larger mass percentages of carbon and vanadium (Table 1). The carbides were fine (up to $2.5 \mu \mathrm{m}$ in diameter) and evenly dispersed in the microstructure as a result of the powder metallurgy manufacturing process. The number of carbides in the microstructure of samples B3 and B4 was higher than in samples B1 and B2, due to the higher tempering temperature $\left(600^{\circ} \mathrm{C}\right)$ and intensified precipitation. The deep cryogenic treatment procedure markedly increased the number of carbides in the microstructure of the grade B steel. 

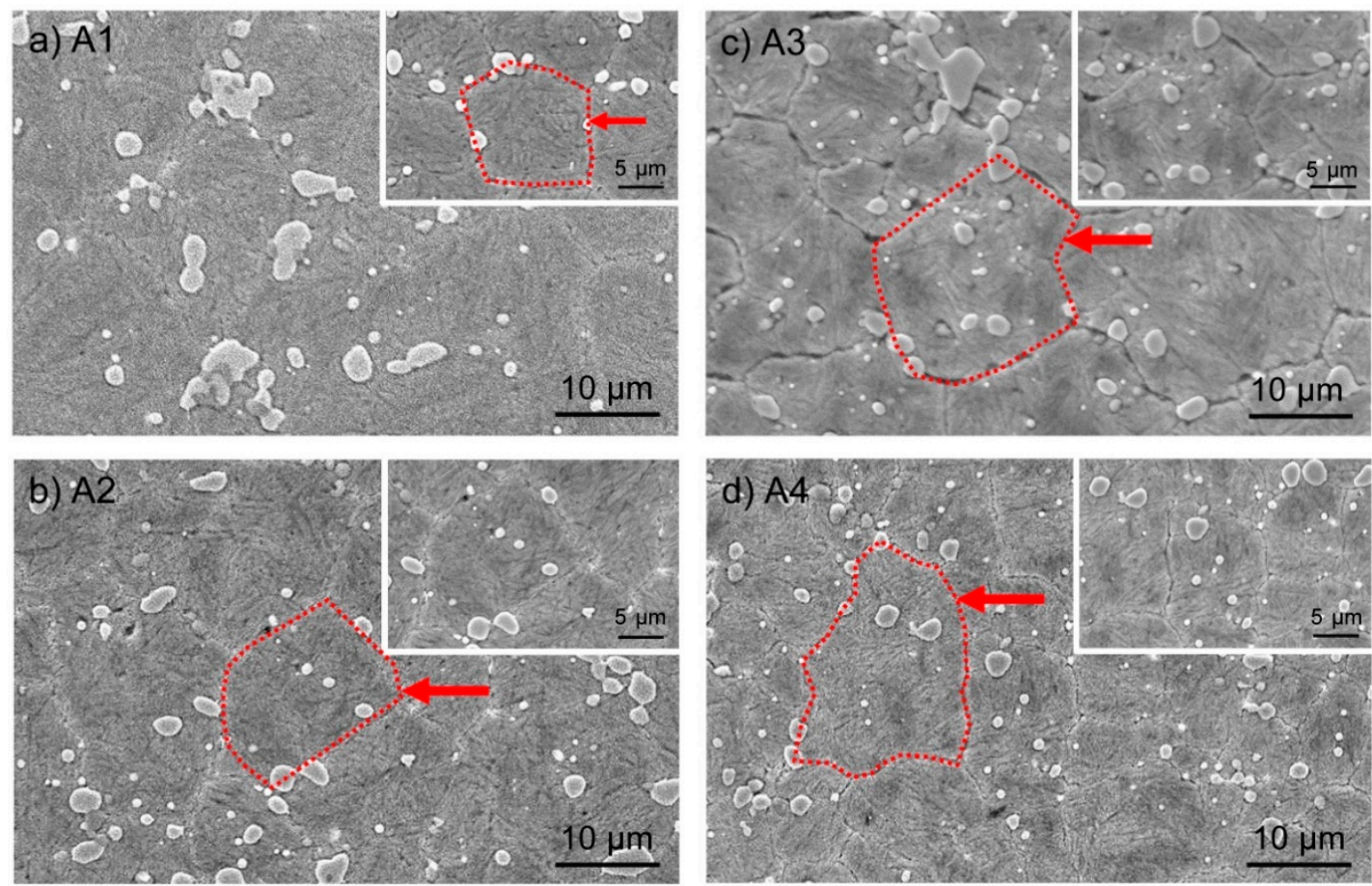

Figure 3. Microstructures of grade A steel after conventional heat treatments: (a) A1: 2 min of austenitization at temperature $T_{\mathrm{A}}=1230{ }^{\circ} \mathrm{C}$ and $3 \times 1 \mathrm{~h}$ tempering at temperature $T_{\mathrm{T}}=550{ }^{\circ} \mathrm{C} ;(\mathbf{c}) \mathrm{A} 3: 2 \mathrm{~min}$ of austenitization at temperature $T_{\mathrm{A}}=1180{ }^{\circ} \mathrm{C}$ and $3 \times 1 \mathrm{~h}$ tempering at temperature $T_{\mathrm{T}}=620^{\circ} \mathrm{C}$; and heat treatment procedures with deep cryogenic treatment: $(\mathrm{b})$ A2: 2 min of austenitization at temperature $T_{\mathrm{A}}=1230{ }^{\circ} \mathrm{C}, 24 \mathrm{~h}$ of DCT at temperature $T_{\mathrm{DCT}}=-196{ }^{\circ} \mathrm{C}$ and $1 \mathrm{~h}$ tempering at temperature $T_{\mathrm{T}}=550{ }^{\circ} \mathrm{C}$; (d) A4: 2 min of austenitization at temperature $T_{\mathrm{A}}=1180{ }^{\circ} \mathrm{C}, 24 \mathrm{~h}$ of DCT at temperature $T_{\mathrm{DCT}}=-196{ }^{\circ} \mathrm{C}$ and $1 \mathrm{~h}$ tempering at temperature $T_{\mathrm{T}}=620^{\circ} \mathrm{C}$.

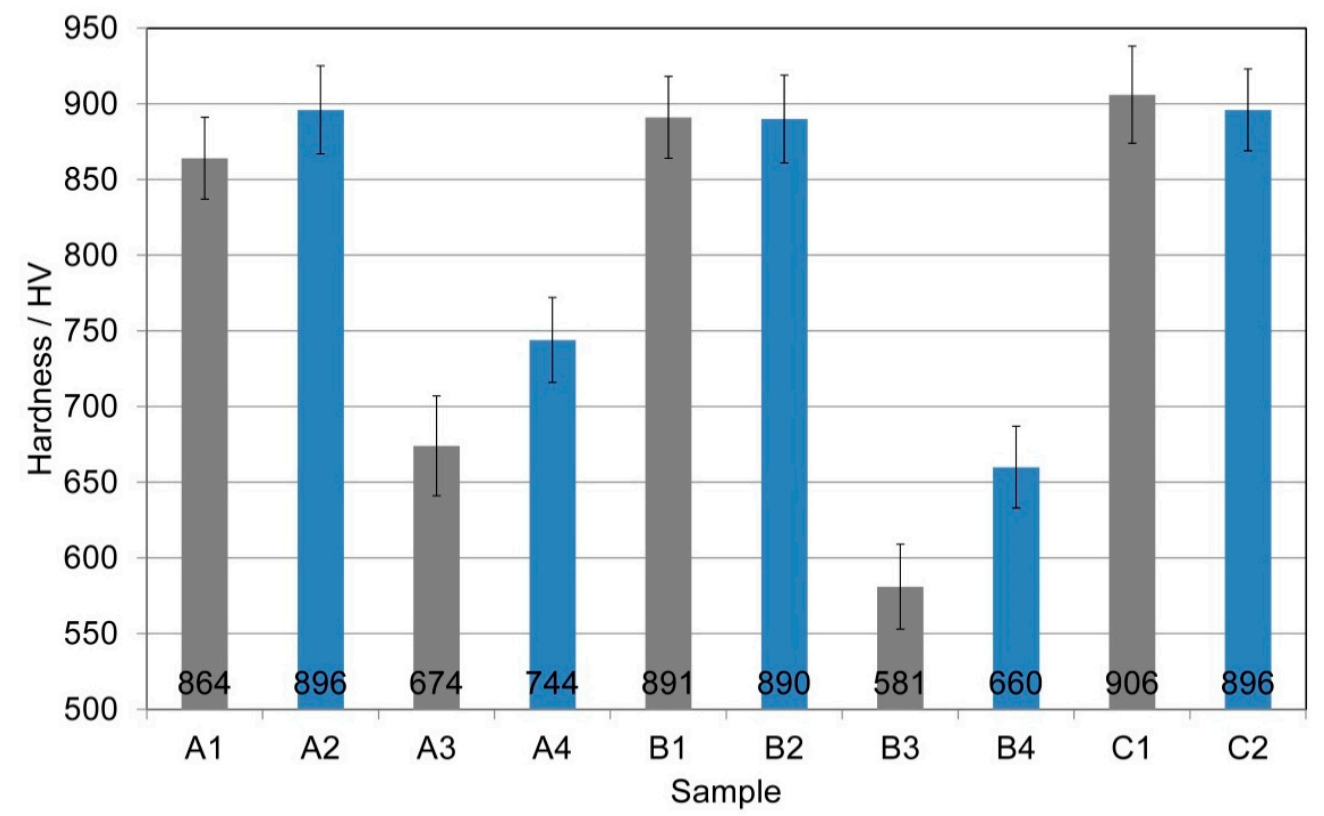

Figure 4. Hardness values of the high-speed steel samples with standard deviation error bars.

Additionally, approximately 30\% lower hardness (581-660 HV vs. 890-891 HV) was obtained in the grade $B$ steel when using low austenitization and high tempering temperature conditions (B3 and B4 samples; Figure 5). With the introduction of the deep cryogenic treatment procedure, there was no noticeable changes in hardness for the high hardness 
grade B steel samples (B1 and B2; high austenitization and low tempering temperature), but a considerable hardness improvement for the low hardness samples (B3 and B4). In the case of grade B steel samples quenched at a low austenitization temperature of $1050{ }^{\circ} \mathrm{C}$ and tempered at $600{ }^{\circ} \mathrm{C}$ deep cryogenic treatment provided an increase in hardness of $13.6 \%$, increasing from $581 \mathrm{HV}$ up to $660 \mathrm{HV}$ (Figure 4).
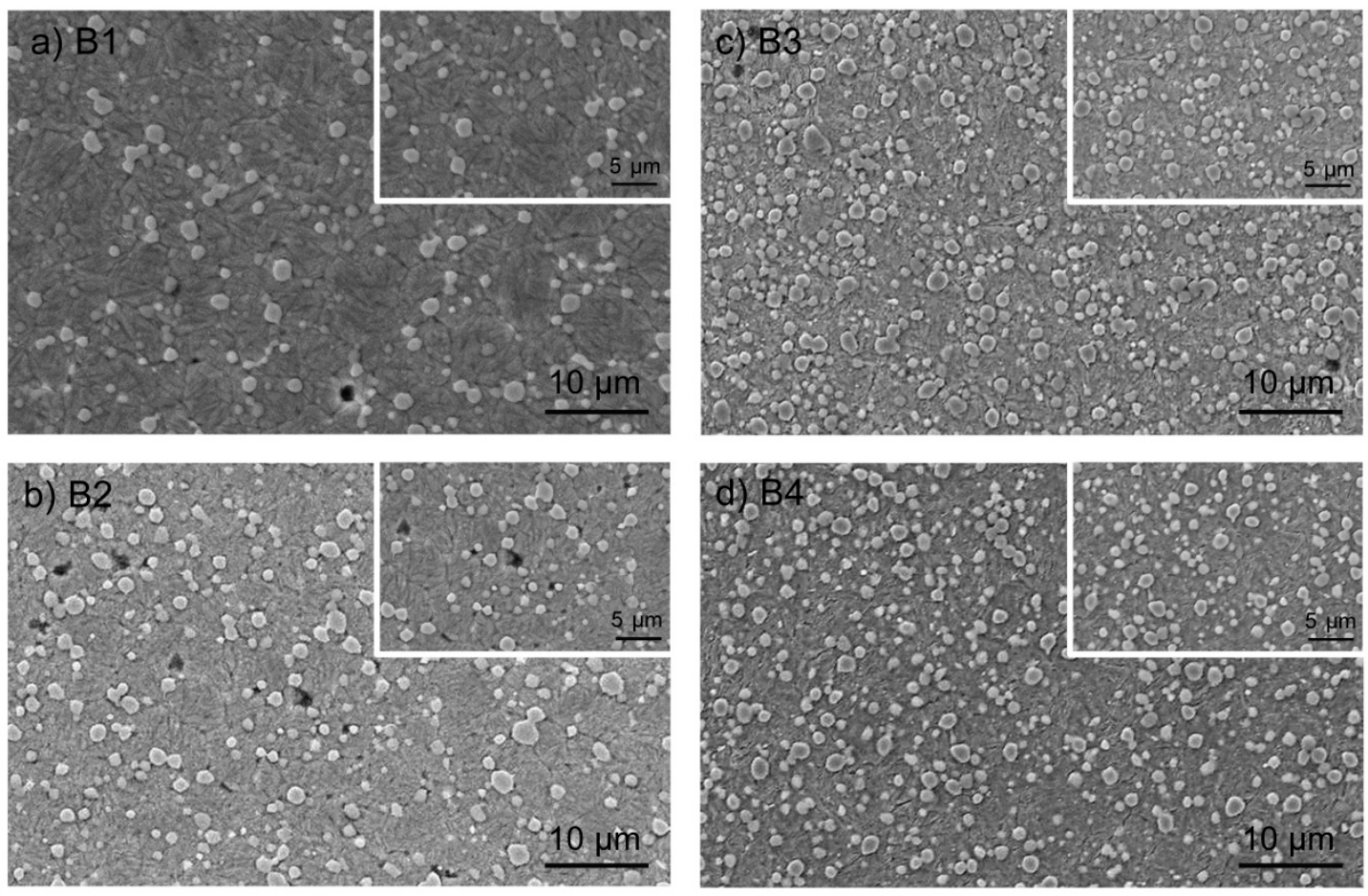

Figure 5. Microstructures of grade B steel after conventional heat treatments: (a) B1: 2 min of austenitization at temperature $T_{\mathrm{A}}=1180{ }^{\circ} \mathrm{C}$ and $3 \times 2 \mathrm{~h}$ tempering at temperature $T_{\mathrm{T}}=540{ }^{\circ} \mathrm{C} ;(\mathbf{c}) \mathrm{B} 3: 6 \mathrm{~min}$ of austenitization at temperature $T_{\mathrm{A}}=1050$ ${ }^{\circ} \mathrm{C}$ and $3 \times 2 \mathrm{~h}$ tempering at temperature $T_{\mathrm{T}}=600{ }^{\circ} \mathrm{C}$; and heat treatment procedures with deep cryogenic treatment: (b) B2: $2 \mathrm{~min}$ of austenitization at temperature $T_{\mathrm{A}}=1180{ }^{\circ} \mathrm{C}, 24 \mathrm{~h}$ of DCT at temperature $T_{\mathrm{DCT}}=-196{ }^{\circ} \mathrm{C}$ and $2 \mathrm{~h}$ tempering at temperature $T_{\mathrm{T}}=540{ }^{\circ} \mathrm{C}$; (d) B4: 6 min of austenitization at temperature $T_{\mathrm{A}}=1050{ }^{\circ} \mathrm{C}, 24 \mathrm{~h}$ of DCT at temperature $T_{\mathrm{DCT}}=$ $-196{ }^{\circ} \mathrm{C}$ and $2 \mathrm{~h}$ tempering at temperature $T_{\mathrm{T}}=600{ }^{\circ} \mathrm{C}$.

The microstructure of grade $C$ steel samples has a needle-like structure of tempered martensite with primary austenite grain boundaries (Figure 6). Most of the carbides were present on the grain boundaries, and some of them are merged together in clusters. The density, size, and distribution of the carbides did not appear to change considerably with the deep cryogenic treatment procedure, at least when using high austenitization and low tempering temperatures. In line with this, the hardness values remained relatively similar both with (C2) or without (C1) implementation of deep cryogenic treatment (Figure 4).

All the high-speed steel samples tested contained a needle-like structure of martensite, residual austenite (below 1\%), and globular carbides, which were in some cases merged in clusters. The heat treatment procedure with deep cryogenic treatment did not appear to drastically change the microstructure of the samples, at least not at the observation level. There was, however, a change in the number and distribution of carbides, especially at low austenitization and high tempering temperature conditions aimed at obtaining lower hardness but higher toughness values (samples A4 and B4). The number of carbides increased, they became less clustered, and their distribution became more uniform, resulting in an increase in hardness. 

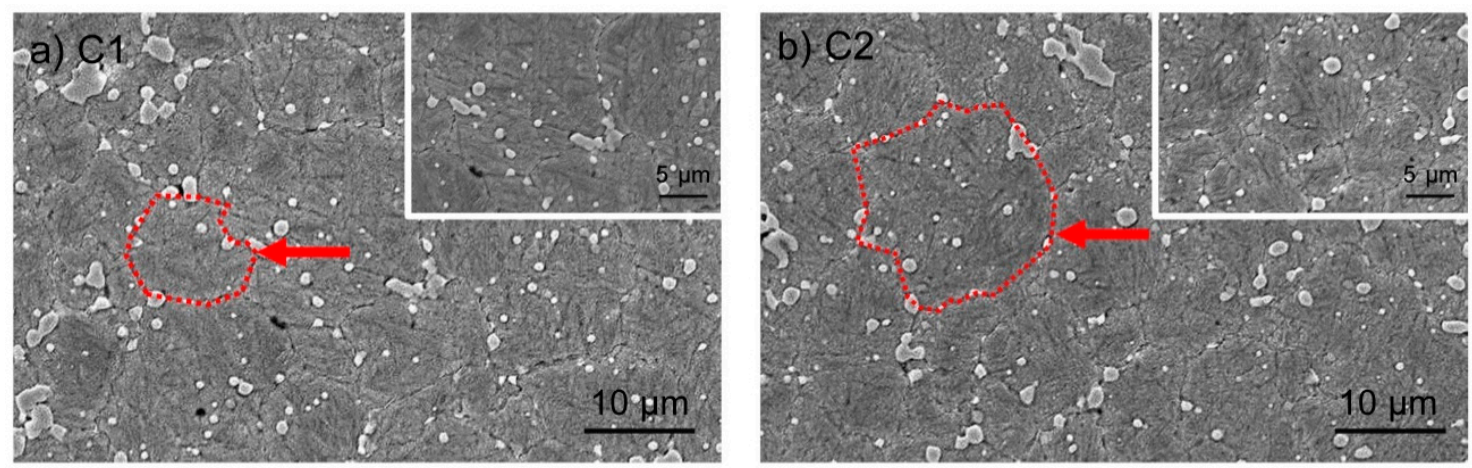

Figure 6. Microstructures of grade $\mathrm{C}$ steel after conventional heat treatment: (a) $\mathrm{C}$ : 2 min of austenitization at temperature $T_{\mathrm{A}}=1230{ }^{\circ} \mathrm{C}$ and $3 \times 2 \mathrm{~h}$ tempering at temperature $T_{\mathrm{T}}=550{ }^{\circ} \mathrm{C}$; and heat treatment with deep cryogenic treatment: (b) C2: 2 min of austenitization at temperature $T_{\mathrm{A}}=1230^{\circ} \mathrm{C}, 24 \mathrm{~h}$ of DCT at temperature $T_{\mathrm{DCT}}=-196^{\circ} \mathrm{C}$ and $2 \mathrm{~h}$ tempering at temperature $T_{\mathrm{T}}=550^{\circ} \mathrm{C}$.

\subsection{Corrosion Properties}

In Figure 7, the corrosion potential and linear polarization measurements were presented for steel grade A steel, namely A1 and A3, and samples A2 and A4, which were deep cryogenically treated.

a)

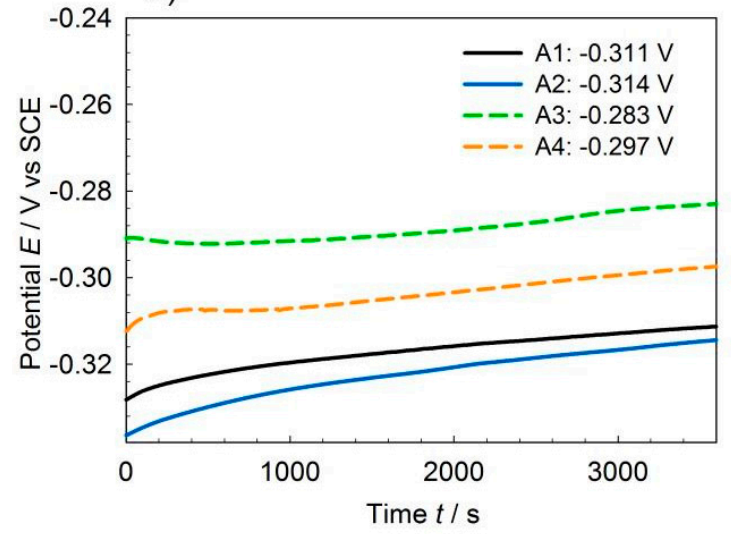

b)

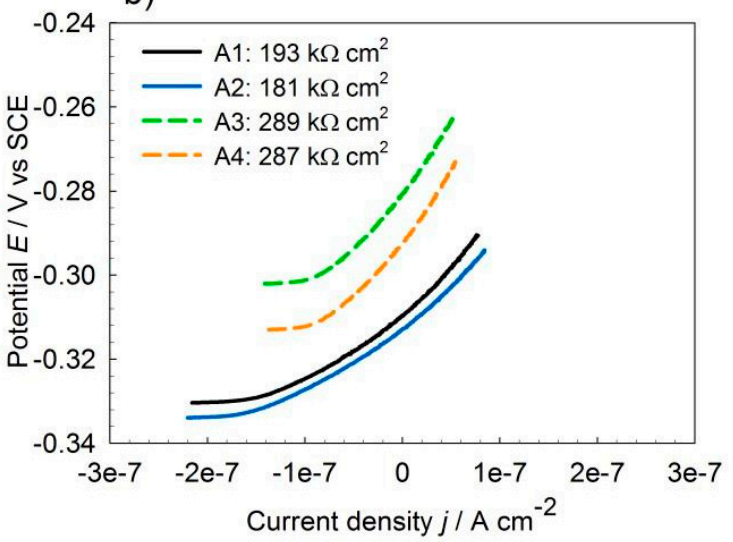

Figure 7. (a) Corrosion potential measurements; (b) linear polarization measurements; for series A steels in a Na-tetraborate buffer, $\mathrm{pH}=10$, at a scan rate of $0.1 \mathrm{mV} / \mathrm{s}$.

The corrosion potentials after $1 \mathrm{~h}$ immersion in the Na-tetraborate buffer was lower for steels A1 and A2 (at $-0.32 \mathrm{~V})$, while the corrosion potential for A3 and A4 were somehow more positive at $-0.29 \mathrm{~V}$. Deep cryogenically treated samples (A2 and A4) have a lower potential than conventionally treated samples (A1 and A3), especially under conditions of low austenitization and high tempering temperatures (A4), which means that their passive layer is less protective.

The polarization resistances, $R_{\mathrm{p}}$, of steels A1 and A2 were $193 \mathrm{k} \Omega \cdot \mathrm{cm}^{2}$ and $181 \mathrm{k} \Omega \cdot \mathrm{cm}^{2}$, respectively. When using a lower austenitizaton temperature $\left(1180{ }^{\circ} \mathrm{C}\right)$ and higher tempering temperature $\left(620^{\circ} \mathrm{C}\right.$; samples $\mathrm{A} 3$ and $\left.\mathrm{A} 4\right)$, hardness was reduced, and the polarization resistance (thus corrosion resistance) for conventionally treated samples (A3) was about $50 \%$ higher, at $289 \mathrm{k} \Omega \cdot \mathrm{cm}^{2}$, and very similar in those samples, which had been cryogenically treated (A4; $287 \mathrm{k} \Omega \cdot \mathrm{cm}^{2}$ ).

The corrosion properties of grade B steel samples are presented in Figure 8. 
a)

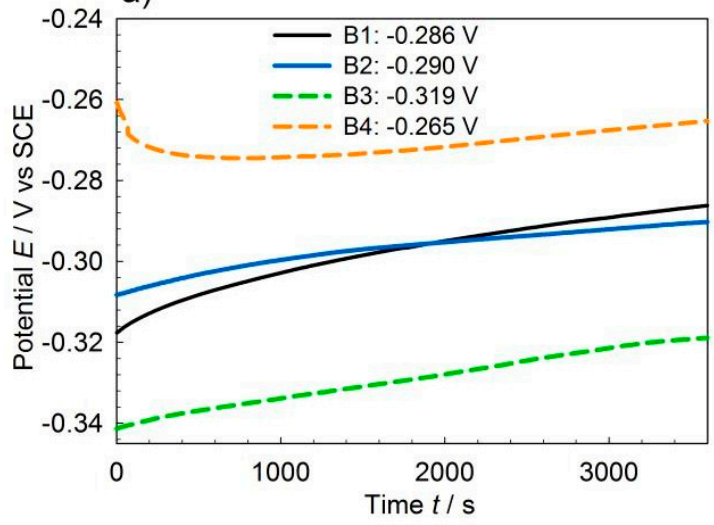

b)

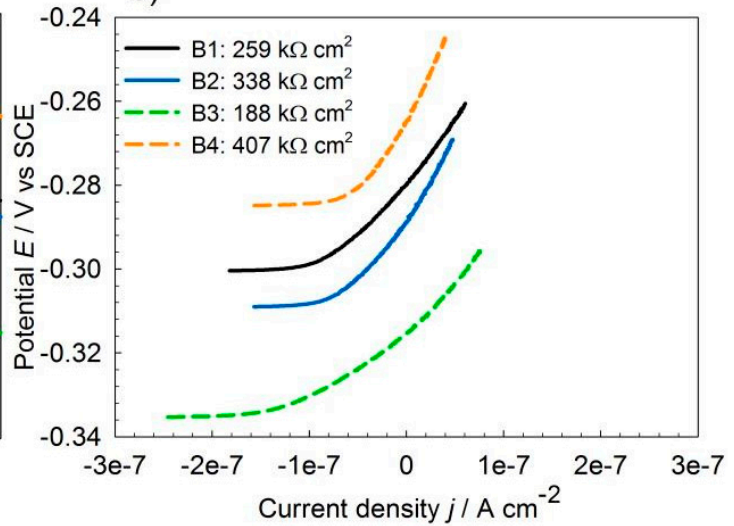

Figure 8. (a) Corrosion potential measurements; (b) linear polarization measurements; for series B steels in a Na-tetraborate buffer, $\mathrm{pH}=10$, at a scan rate of $0.1 \mathrm{mV} / \mathrm{s}$.

The corrosion potentials for samples B1 and B2 (higher austenitization and lower tempering temperatures) were very similar, at $-0.29 \mathrm{~V}$. Using a lower austenitization and higher tempering temperature, however, the corrosion potential was most negative in conventionally heat-treated samples (B3), at $-0.32 \mathrm{~V}$, changing to the most positive values $(-0.27 \mathrm{~V})$ with deep cryogenic treatment (B4). By comparing the corrosion potential measurements in samples B3 and B4, it can be deduced that deep cryogenic treatment was the most effective method, as the high positive change in corrosion potential inferred an improvement in corrosion in sample B4, which had been deep cryogenically treated.

The polarization resistance, $R_{\mathrm{p}}$, of grade $\mathrm{B}$ steel was quite different when compared to grade A steel, also when considering the influence of deep cryogenic treatment. For steel samples treated at higher austenitization/lower tempering temperatures, $R_{\mathrm{p}}$ for B1 was $259 \mathrm{k} \Omega \cdot \mathrm{cm}^{2}$, while $R_{\mathrm{p}}$ for the deep cryogenically treated sample B2 was much higher at $338 \mathrm{k} \Omega \cdot \mathrm{cm}^{2}$. A similar trend but to a much higher extent was also observed under conditions of lower austenitization/higher tempering temperatures. The polarization resistance of B3 samples was as low as $188 \mathrm{k} \Omega \cdot \mathrm{cm}^{2}$, while the DCT process (B4) markedly increased $R_{\mathrm{p}}$ to $407 \mathrm{k} \Omega \cdot \mathrm{cm}^{2}$.

In the case of grade B high-speed steel, deep cryogenically treated samples exhibited better corrosion properties (31\% for high hardness conditions-B2 and, 116\% for low hardness conditions-B4) than their conventionally heat-treated counterparts.

Electrochemical results for grade $C$ steel are presented in Figure 9.
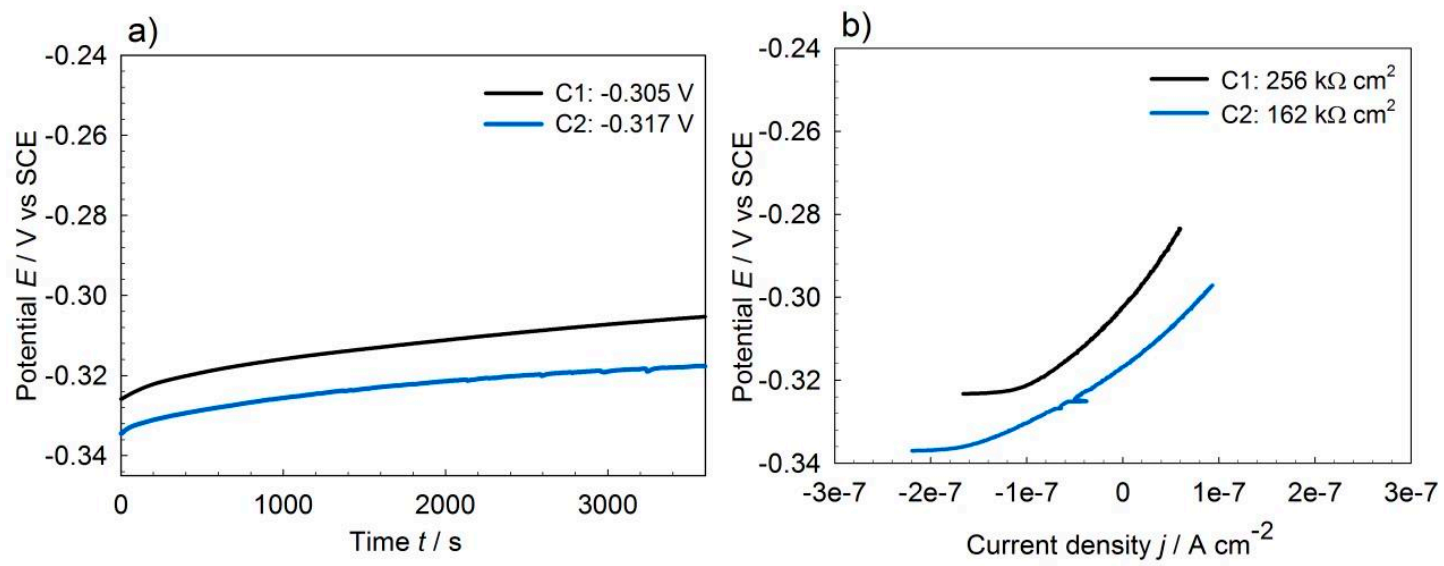

Figure 9. (a) Corrosion potential measurements; (b) linear polarization measurements; for series C steels in a Na-tetraborate buffer, $\mathrm{pH}=10$, at a scan rate of $0.1 \mathrm{mV} / \mathrm{s}$. 
The corrosion potentials for grade C steel were similar to those for series A and B when heat-treated at high austenitization and low tempering conditions. The polarization resistance $R_{\mathrm{p}}$ for conventionally treated grade C steel (C1) was $256 \mathrm{k} \Omega \cdot \mathrm{cm}^{2}$, while the deep cryogenically treated sample (C2) had a lower $R_{\mathrm{p}}$ value at $162 \mathrm{k} \Omega \cdot \mathrm{cm}^{2}$. Deep cryogenic treatment evidently worsens the corrosion properties of grade $C$ high-speed steel, deteriorating it by $37 \%$.

\section{Discussion}

Polarization resistance values and the distribution of the measured data are presented in Figure 10. The scatter diagram in Figure 10b compares the $R_{\mathrm{p}}$ values for the different grades of high-speed steel and heat treatment procedures. Logarithmic values of $R_{\mathrm{p}}$ for conventionally treated samples are shown in grey, and deep cryogenically treated samples are in blue. The arrows point at dots representing the value closest to the average, and the red dots represent outliers, the measured values that were omitted during estimation of the mean. It can be seen that no considerable change in corrosion properties can be observed after deep cryogenic treatment on grade A steel, while corrosion properties deteriorate with DCT in grade C steels. DCT markedly improves corrosion properties of grade B high-speed steel, however, namely by $31 \%$ when hardened to high hardness values (B2 vs. B1) and by as much as 116\% under lower hardness conditions (B4 vs. B3).

a)

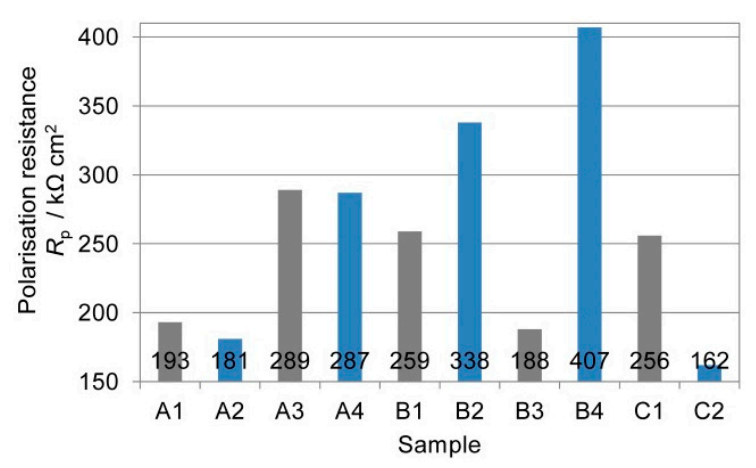

b)

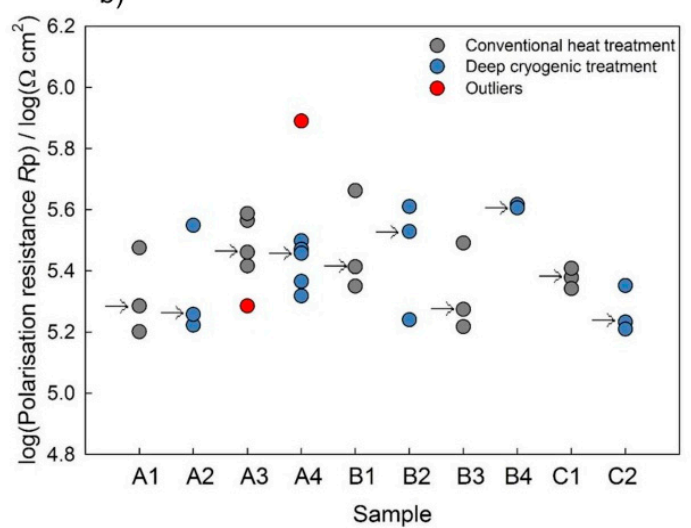

Figure 10. (a) Comparison of polarization resistance values; (b) scatter diagram of measurements on steel grades A, B and C in a Na-tetraborate buffer, $\mathrm{pH} 10$.

To elucidate the corrosion properties of different steels, corrosion rates were estimated. Corrosion rates were deduced from the $R_{\mathrm{p}}$ values obtained (Table 2) by using the following equation, where corrosion rate, $v_{\text {corr }}$, in $\mu \mathrm{m} /$ year is calculated according to Faraday law [27]:

$$
v_{\text {corr }}=3.27 \cdot\left(j_{\text {corr }} \cdot w / M\right) /(d \cdot n),
$$

where $j_{\text {corr }}$ stands for corrosion current density in $\mu \mathrm{A} \mathrm{cm}{ }^{-2}, d$ density of steel $\left(d=7,8 \mathrm{~g} \mathrm{~cm}^{-3}\right)$, $w$ atomic mass ( $w / M=58$ without units) and $n(n=2)$ number of exchanged electrons. 
Table 2. Corrosion potential $E_{\text {corr }}$, polarization resistance $R_{\mathrm{p}}$, corrosion current density $j_{\text {corr }}$, and corrosion rates $v_{\text {corr }}$ for the differing steel grades $\mathrm{A}, \mathrm{B}$, and $\mathrm{C}$.

\begin{tabular}{ccccc}
\hline Sample & $E_{\text {corr }} \mathbf{( V )}$ & $\boldsymbol{R}_{\mathbf{p}}\left(\mathbf{k} \boldsymbol{\Omega} \cdot \mathbf{c m}^{\mathbf{2}}\right)$ & $j_{\text {corr }}\left(\mu \mathrm{A} / \mathbf{c m}^{2}\right)$ & $\nu_{\text {corr }}(\mu \mathrm{m} /$ year $)$ \\
\hline A1 & -0.310 & 193 & 0.135 & 1.56 \\
A2 & -0.313 & 181 & 0.144 & 1.67 \\
A3 & -0.281 & 289 & 0.0901 & 1.05 \\
A4 & -0.293 & 287 & 0.0907 & 1.05 \\
\hline B1 & -0.280 & 259 & 0.101 & 1.17 \\
B2 & -0.293 & 338 & 0.0772 & 0.894 \\
B3 & -0.315 & 188 & 0.139 & 1.61 \\
B4 & -0.265 & 407 & 0.0639 & 0.742 \\
\hline C1 & -0.302 & 256 & 0.102 & 1.18 \\
C2 & -0.317 & 162 & 0.161 & 1.86 \\
\hline
\end{tabular}

$j_{\text {corr }}$ was calculated from the equation using the Stearn-Geary approximation of the Tafel coefficients:

$$
j_{\text {corr }}=\left(1 /\left(2.303 \cdot R_{\mathrm{p}}\right)\right) \cdot\left(\beta_{\mathrm{A}} \cdot \beta_{\mathrm{C}} /\left(\beta_{\mathrm{A}}+\beta_{\mathrm{C}}\right)\right),
$$

$\beta_{\mathrm{A}}$ and $\beta_{\mathrm{C}}$ being $120 \mathrm{mV}$ per decade.

As can be seen from Table 2, corrosion rate as a measure for the loss of material due to general types of corrosion to which most steels are subjected is dependent on the type of steel, chemical composition, and heat treatment procedure, even within one group type (i.e., high-speed steel). In the case of grade B steel, the corrosion rate is reduced by deep cryogenic treatment (B2 and B4), for grade A steel, the corrosion rate remains more or less the same, while for grade $C$ steel, the corrosion rate even increases with deep cryogenic treatment ( $\mathrm{C} 2$ vs. $\mathrm{C} 1)$. The microstructural properties and chemical composition of the samples influence their corrosion resistance. Microstructural properties include (i) the volume fractions of retained austenite, martensite, and carbides, (ii) the shape, size, type, and distribution of carbides, and (iii) the size of the primary austenitic crystal grains.

In the current investigation, the following correlations between microstructural features and corrosion characteristics can be made. The microstructure of grade A steel consists of tempered martensite, with most of the carbides being globular and larger ones located on the primary austenite grain boundaries. A very similar microstructure, without any marked differences, is observed regardless of the heat treatment conditions and procedure used (conventional vs. deep cryogenic treatment). This could be the primary reason that the corrosion resistance is similar after both types of treatment in grade A steel. Corrosion resistance (polarization resistance) of grade A high-speed steel does not appear to significantly change with cryogenic heat treatment (Table 2).

In the case of grade B steel, the microstructure shows an increase in the number of precipitated carbides, and they are more homogeneously distributed after deep cryogenic treatment, a change that is especially pronounced under low austenitization/high tempering temperature conditions (B4 vs. B3). The corrosion resistance is markedly improved for both of the applied austenitization and tempering temperature combinations. The observed improvement in corrosion resistance of grade B steel after the process of deep cryogenic treatment might be due to an increased number and more homogeneous distribution of spherical carbide precipitations within the crystal grains. Fine nano-sized carbides might also form in the microstructure of grade B steel samples during deep cryogenic treatment, as observed by Amini et al. [5], thus assisting an improvement in corrosion resistance.

In grade $C$ steel, a decrease in $R_{p}$ was identified. In the case of grade $C$ steel, carbides are mainly located along the crystal grain boundaries and have a more irregular edgetype shape. Furthermore, when compared to steel grades A and B, the matrix of grade $\mathrm{C}$ steel contains coarser martensite laths, which might also have a negative effect on the corrosion resistance. 
It was shown in this study that the microstructural and corrosion properties of each type of high-speed steel are unique, varying according to their chemical composition and the type of heat treatment used (conventional or deep cryogenic).

\section{Conclusions}

Microstructural and electrochemical investigations were used in this study to evaluate the corrosion properties of different types of high-speed steels subjected to different heat treatments. The effect of deep cryogenic treatment was studied.

(1) Microstructural investigation showed that deep cryogenic treatment increases the number and dispersion of carbides, especially in the case of steel grade B-AISI M3:2 (EN 1.3395), and when using heat treatment conditions resulting in lower hardness values (high austenitization/low tempering temperatures). However, for grades A-AISI M2 (EN 1.3343) and C-AISI M35 (EN 1.3243), reduced carbide clusters were observed when they were subjected to deep cryogenic treatment.

(2) Hardness remained unchanged if deep cryogenic treatment was used in combination with high austenitization/low tempering heat treatment protocols. There was a considerable increase in hardness, however, when heat treatment protocols utilized lower austenitization and higher tempering temperatures.

(3) Electrochemical measurements were conducted after careful consideration of four different corrosion mediums. It was shown that Na-tetraborate buffer at $\mathrm{pH} 10$ enables differentiation between the corrosion resistance of high-speed steels with a relatively small difference in corrosion resistance caused by microstructural changes due to variations in heat treatment protocols. Such corrosion studies have not been available and used before. The present corrosion evaluation of the effect of deep cryogenic treatment is unique and reported for the first time, according to the authors' best knowledge.

(4) There was no improvement in the polarization resistances of grade A high-speed steels after deep cryogenic treatment, while grade $C$ even showed some deterioration. Grade B steel, however, showed increased polarization resistances and thus higher corrosion resistivity after deep cryogenic treatment, which can be related to an increased number and more homogeneous distribution of precipitated carbides within the grains. Precipitates in grade A and C steels, on the other hand, are mainly distributed along the primary austenite grain boundaries, especially in grade C steel, which has a more irregular shape.

(5) The classically produced high-speed steel (grades A and C) did not respond favorably to deep cryogenic treatment, whereas the powder metallurgy produced high-speed steel (grade B) with a very fine microstructure showed promising results after deep cryogenic treatment. In the case of PM grade B high-speed steel, the deep cryogenic treatment had the best combined effect on both corrosion resistance and mechanical properties when the steel was hardened to low hardness values (sample B4). In this case, the polarization resistance is $116 \%$ higher, while the hardness is improved by $13.6 \%$ compared to the equivalent sample conventionally heat-treated counterpart.

Author Contributions: The authors have all contributed to the paper submitted. Prepared the original draft of the manuscript, J.V.; performed electrochemical tests, Ž.N.; supervised manuscript writing, designed the experiments and analyzed data, T.K.; prepared samples P.J.-K.; edited and reviewed manuscript and supervised the project, B.P. All authors have read and agreed to the published version of the manuscript.

Funding: The authors declare that they have no known competing financial interests or personal relationships that could influence the work reported in this paper.

Institutional Review Board Statement: Not applicable.

Informed Consent Statement: Not applicable. 
Data Availability Statement: The data that support the findings of this study are available from the corresponding authors upon reasonable request.

Acknowledgments: This work is supported by the Slovenian Research Agency within the project No. J2-9211.

Conflicts of Interest: The authors declare no conflict of interest.

\section{Nomenclature}

$\mathrm{A} \& \mathrm{Q}$

M2

$d$

DCT

E

$E_{\text {corr }}$

EIS

ESR

HRC

HSS

HV

ICP-OES

j

$j_{\text {corr }}$

LPR

M3:2

M35

$n$

OCP

$R_{\mathrm{a}}$

$R_{\mathrm{p}}$

SCE

SEM

$\mathrm{T}$

$T_{\mathrm{A}}$

$t_{\mathrm{A}}$

$T_{\text {DCT }}$

$T_{\mathrm{T}}$

$t_{\mathrm{T}}$

$\beta_{\mathrm{A}}$

$\beta_{\mathrm{C}}$

$v_{\text {corr }}$

$\omega$
Austenitization and quenching

AISI label for high speed steel EN 1.3343

Density

Deep cryogenic treatment

Potential

Corrosion potential

Electrochemical impedance spectroscopy

Electro-slag remelting

Hardness Rockwell C

High speed steel

Vickers Hardness

Inductively coupled plasma-optical emission spectrometry

Current density

Corrosion current density

Linear polarization

AISI label for high speed steel EN 1.3243

AISI label for high speed steel EN 1.3395

Number of exchanged electrons

Open circuit potential measurement

Surface Roughness $(\mu \mathrm{m})$

Polarization resistance

Saturated calomel electrode

Scanning electron microscope

Tempering

Austenitization temperature

Austenitization period

Deep cryogenic treatment temperature

Tempering temperature

Tempering period

Tafel anodic coefficient

Tafel cathodic coefficient

Corrosion rate

Atomic mass 


\section{Appendix A}

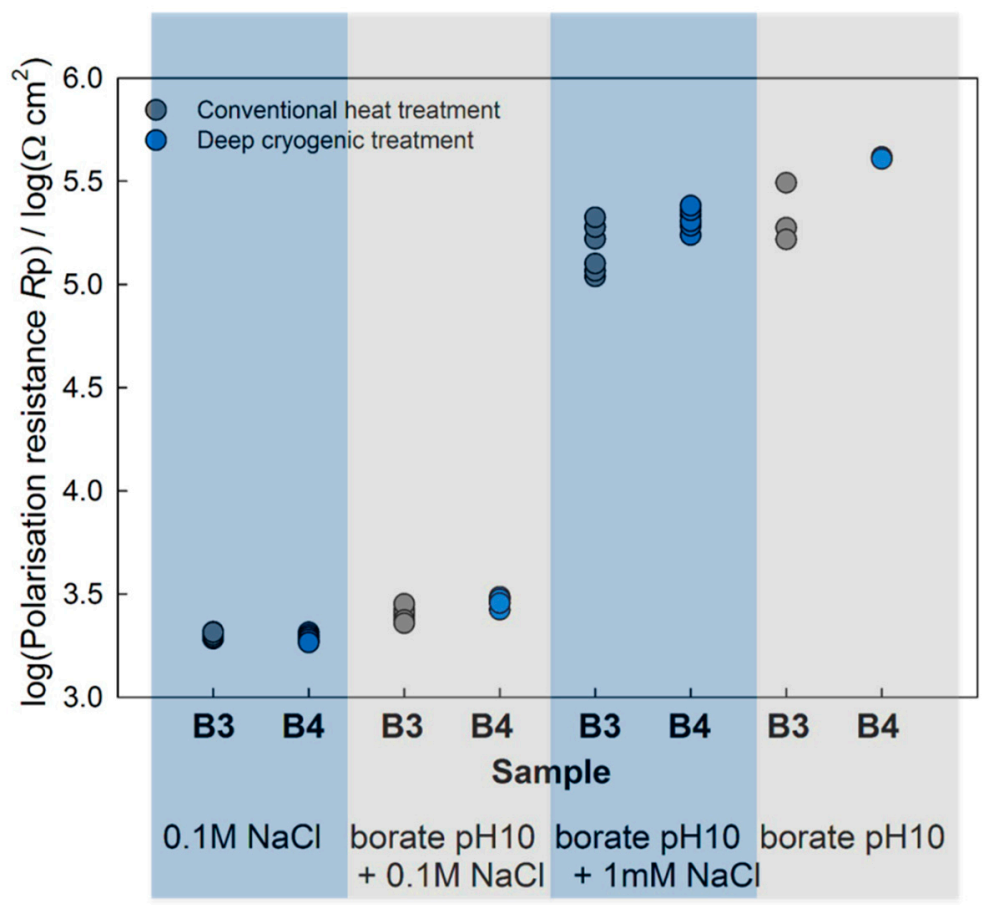

Figure A1. Scatter diagram of measurements on steel grade B in different aqueous solutions.

\section{References}

1. Totten, G.E. Steel Heat Treatment: Metallurgy and Technologies; Taylor \& Francis Group: Boca Raton, FL, USA, 2006.

2. Razavykia, A.; Delprete, C.; Baldissera, P. Correlation between microstructural alteration, mechanical properties and manufacturability after cryogenic treatment: A review. Materials 2019, 12, 3302. [CrossRef] [PubMed]

3. Amini, K.; Akhbarizadeh, A.; Javadpour, S. Cryogenic heat treatment-A review of the current state. Metall. Mater. Eng. 2017, $23,1$. [CrossRef]

4. Sonar, T.; Lomte, S.; Gogte, C. Cryogenic Treatment of Metal-A Review. Mater. Today Proc. 2018, 5, 25219-25228. [CrossRef]

5. Amini, K.; Akhbarizadeh, A.; Javadpour, S. Effect of deep cryogenic treatment on the formation of nano-sized carbides and the wear behavior of D2 tool steel. Int. J. Miner. Metall. Mater. 2012, 19, 795-799. [CrossRef]

6. Das, D.; Dutta, A.K.; Toppo, V.; Ray, K.K. Effect of deep cryogenic treatment on the carbide precipitation and tribological behavior of D2 steel. Mater. Manuf. Process. 2007, 22, 474-480. [CrossRef]

7. Firouzdor, V.; Nejati, E.; Khomamizadeh, F. Effect of deep cryogenic treatment on wear resistance and tool life of M2 HSS drill. J. Mater. Process. Technol. 2008, 206, 467-472. [CrossRef]

8. Kuřík, M.; Lacza, J.; Vlach, T.; Sobotová, J. Study of the properties and structure of selected tool steels for cold work depending on the parameters of heat treatment. Mater. Tehnol. 2017, 51, 585-589. [CrossRef]

9. Oppenkowski, A.; Weber, S.; Theisen, W. Evaluation of factors influencing deep cryogenic treatment that affect the properties of tool steels. J. Mater. Process. Technol. 2010, 210, 1949-1955. [CrossRef]

10. Rhyim, Y.M.; Han, S.H.; Na, Y.S.; Lee, J.H. Effect of deep cryogenic treatment on carbide precipitation and mechanical properties of tool steel. Solid State Phenom. 2006, 118, 9-14. [CrossRef]

11. Gill, S.S.; Singh, J.; Singh, R.; Singh, H. Effect of cryogenic treatment on AISI M2 high speed steel: Metallurgical and mechanical characterization. J. Mater. Eng. Perform. 2012, 21, 1320-1326. [CrossRef]

12. Gavriljuk, V.G.; Sirosh, V.A.; Petrov, Y.N.; Tyshchenko, A.I.; Theisen, W.; Kortmann, A. Carbide precipitation during tempering of a tool steel subjected to deep cryogenic treatment. Metall. Mater. Trans. A Phys. Metall. Mater. Sci. 2014, 45, 2453-2465. [CrossRef]

13. Aggarwal, V.; Pruncu, C.I.; Singh, J.; Sharma, S.; Pimenov, D.Y. Empirical Investigations during WEDM of Ni-27Cu-3.15Al2Fe-1.5Mn Based Superalloy for High Temperature Corrosion Resistance Applications. Materials 2020, 13, 3470. [CrossRef] [PubMed]

14. Jovičević-Klug, P.; Podgornik, B. Review on the effect of deep cryogenic treatment of metallic materials in automotive applications. Metals 2020, 10, 434. [CrossRef]

15. Jovičević-Klug, P.; Jovičević-Klug, M.; Podgornik, B. Effectivness of deep cryogenic treatment on carbide precipitation. J. Mater. Res. Technol. 2020, 9, 13014-13026. [CrossRef] 
16. Jovičević-Klug, P.; Podgornik, B. Comparative study of conventional and deep cryogenic treatment of AISI M3:2 (EN1.3395) highspeed steel. J. Mater. Res. Technol. 2020, 9, 13118-13127. [CrossRef]

17. Cajner, F.; Leskovsek, V.; Landek, D.; Cajner, H. Effect of deep-cryogenic treatment on high speed steel properties. Mater. Manuf. Process. 2008, 24, 743-746. [CrossRef]

18. Molinari, A.; Pellizzari, M.; Gialanella, S.; Straffelini, G.; Stiasny, K.H. Effect of deep cryogenic treatment on the mechanical properties of tool steels. J. Mater. Process. Technol. 2001, 118, 350-355. [CrossRef]

19. Leskovšek, V.; Kalin, M.; Vižintin, J. Influence of deep-cryogenic treatment on wear resistance of vacuum heat-treated HSS. Vacuum 2006, 80, 507-518. [CrossRef]

20. Huang, J.Y.; Zhu, Y.T.; Liao, X.Z.; Beyerlein, I.J.; Bourke, M.A.; Mitchell, T.E. Microstructure of cryogenic treated M2 tool steel. Mater. Sci. Eng. A 2003, 339, 241-244. [CrossRef]

21. Gill, S.S.; Singh, J.; Singh, R.; Singh, H. Metallurgical principles of cryogenically treated tool steels-A review on the current state of science. Int. J. Adv. Manuf. Technol. 2011, 54, 59-82. [CrossRef]

22. Podgornik, B.; Leskovsek, V.; Vizintin, J. Influence of deep-cryogenic treatment on tribological properties of P/M high-speed steel. Mater. Manuf. Process. 2009, 24, 734-738. [CrossRef]

23. Podgornik, B.; Majdic, F.; Leskovsek, V.; Vizintin, J. Improving tribological properties of tool steels through combination of deep-cryogenic treatment and plasma nitriding. Wear 2012, 288, 88-93. [CrossRef]

24. Baldissera, P.; Delprete, C. Deep cryogenic treatment of AISI 302 stainless steel: Part II—Fatigue and corrosion. Mater. Des. 2010, 31, 4731-4737. [CrossRef]

25. Pourbaix, M. Atlas of Electrochemical Equilibria in Aqueous Solutions, 2nd ed.; National Association of Corrosion Engineers: Huston, TX, USA, 1974.

26. Tait, W.S. An Introduction to Electrochemical Corrosion Testing for Practicing Engineers and Scientists; PairODocs Publications: Racine, WI, USA, 1994.

27. Elsener, B. Corrosion rate of steel in concrete-Measurements beyond the Tafel law. Corros. Sci. 2005, 47, 3019-3033. [CrossRef] 